\title{
Partitioning and Modeling of Biomass in Caatinga Legume Seedlings in Different Water Conditions
}

\author{
João Paulo Alves de Barros ${ }^{1}$, Luciana Sandra Bastos Souza ${ }^{1}$, \\ Thieres George Freire da Silva ${ }^{1}$ (D), Magna Soelma Beserra de Moura ${ }^{2}$, \\ Luzia Ferreira da Silva ${ }^{1}$ \\ ${ }^{1}$ Unidade Acadêmica de Serra Talhada, Universidade Federal Rural de Pernambuco - UFRPE, Serra Talhada/PE, Brasil \\ ${ }^{2}$ Laboratório de Agrometeorologia, Empresa Brasileira de Pesquisa Agropecuária - EMBRAPA, Petrolina/PE, Brasil
}

\begin{abstract}
The accumulation of dry biomass, its partitioning and the adjustment of equations were assessed for the initial growth of Piptadenia stipulacea (Benth) Ducke and Anadenanthera colubrina (Vell.) Brenan under water availability variation. The experiment was conducted in pots arranged in a completely randomized design with three replicates. Water conditions were evaluated using the percentages of reference evapotranspiration. Samples of the biomass were taken at 10-day intervals and used for the achievement of partitioning data and model adjustments. The short period of water scarcity in the initial growth phase of $P$. stipulacea and A. colubrina does not affect the establishment of these species, but different water regimes alter their root growth dynamics. The A. colubrina allocates more dry matter to the roots, while $P$. stipulacea sends more dry matter to the aerial part. The Gaussian, Lorentzian, Log-Normal and Gompertz models had excellent adjustments for the biomass variables of the P. stipulacea species, whereas for A. colubrina, we recommend the Exponential model.
\end{abstract}

Keywords: Anadenanthera colubrina (Vell.) Brenan, initial plant growth, Piptadenia stipulacea (Benth) Ducke, semiarid, water deficit. 


\section{INTRODUCTION}

The Caatinga comprises the only example of seasonally dry tropical forests in Brazil (Silva et al., 2017). This plant cover is exposed to several types of environmental stresses, which are the outcome of the interaction among several factors such as: water availability (Souza et al., 2010) and soil nutrients (Menezes et al., 2012), in addition to climate (Silva et al., 2017; Souza et al., 2010). The climate is characterized for presenting high temperatures $\left(23-27^{\circ} \mathrm{C}\right)$, low air relative humidity, and volumes of rainfall (300-800 $\mathrm{mm}$ annually) poorly distributed in space and time (Alvalá et al., 2017). The combination of these factors results in high atmospheric demand, and reduced water availability, with periods of no rain in the rainy season that can last up to 19 days (Soares \& Nóbrega, 2010).

The species from the Caatinga have developed morphophysiological and biochemical mechanisms to withstand adverse environmental conditions (Costa et al., 2015; Figueiredo-Lima et al., 2018), particularly the water deficit. However, the responses depend on the species, degree of stress and time of occurrence, especially in the initial stage of growth, which represents the most sensitive phase to the establishment of the plant in the environment (Lúcio et al., 2017).

The species Piptadenia stipulacea (Benth) Duck and Anadenanthera colubrina (Vell.) Brenan are native to the Caatinga Domain and have been used for economic, social and environmental purposes (Lorenzi, 2009). They present rapid growth and one way to understand the responses to environmental stresses is through dry biomass and its directly partitioning (Gonçalves et al., 2013), as well as the mathematical modeling, which can be applied in highly dynamic environments (Pinheiro et al., 2015; Silva et al., 2015).

The use of the modeling enables an integrated analysis of the biophysical knowledge that governs the soil-plant-atmosphere system, allowing to evaluate the uncertainties associated with environmental modifications. Regarding the semi-arid reality, however, Silva et al. (2015) cite that few studies use simulation of native plant growth, unlike other Brazilian morphoclimatic domains. The understanding of responses to water deficit may help the development of strategies for the production of seedlings, conservation of the environment and restoration of native forests in degraded areas.

This study investigated the accumulation of dry biomass and its partitioning, and adjusts mathematical models to the initial growth of two Caatinga legume species: P. stipulacea and A. colubrina under different levels of water availability in Serra Talhada, State of Pernambuco.

\section{MATERIAL AND METHODS}

\subsection{Characterization of the experimental area}

The experiment was conducted from November 23, 2016 to March 28, 2017 at Unidade Acadêmica de Serra Talhada (Latitude: $07^{\circ} 95^{\prime} 42^{\prime \prime}$ S; Longitude: $38^{\circ} 29^{\prime} 50^{\prime \prime} \mathrm{O}$; $499 \mathrm{~m}$ above sea level), located in the municipality of Serra Talhada, state of Pernambuco. The climate of the region is BShw' of semi-arid type according to the classification of Köppen, with high average temperatures of approximately $26^{\circ} \mathrm{C}$ and low air relative humidity with annual average around $63 \%$ and low rainfall volumes, with an average of $642 \mathrm{~mm}$.year ${ }^{-1}$ (Table 1), concentrated in few days in the year, occurring especially from January to April (Pereira et al., 2015). The meteorological data of the experiment period were obtained of a weather station owned by the National Institute of Meteorology (INMET) and are presented in Figure 1. The soil was classified as typical Tb Eutrophic Haplic Cambisol (Santos et al., 2013).

The pots were arranged in $0.3 \mathrm{~m} \times 0.3 \mathrm{~m}$ spacing and completely randomized experimental design with three replications, in $2 \times 4$ factorial arrangement, being two species and four water regimes. The pots were located on bricks and each was considered a sample unit, with plots consisting of a total of 18 pots. The observations were carried out in protected environment under type $70 \%$ commercial shade cloth. The species A. colubrina and $P$. stipulacea were used. The seeds were initially scarified with no.100 sandpaper, at the end opposite the hilium. Then, they were sown in polypropylene containers with a capacity of $300 \mathrm{~mL}$, filled with soil collected in the experimental area and sieved through a $2 \mathrm{~mm}$ mesh, then mixed with washed sand at a 2:1 proportion and covered with vermiculite. Water was resuplied daily. Thirty days after sowing, 144 plants were transplanted into $5 \mathrm{~L}$ pots, filled with the same soil from the containers 
Table 1. Analysis of variance of the leaf dry biomass (LDB), stem dry biomass (SDB), root dry biomass (RDB), total aerial part dry biomass (TAPDB), total dry biomass (TDB), leaf area (LA) and root ratio (DRB/TDSB).

\begin{tabular}{|c|c|c|c|c|}
\hline Variable & Source of Variation & Sum of Squares & Middle Square & $\mathbf{F}$ \\
\hline \multirow{3}{*}{ LDB } & Species & 4.21975 & 4.21975 & $12.0196^{\star *}$ \\
\hline & Water regime & 1.26369 & 0.42123 & $1.1998 \mathrm{~ns}$ \\
\hline & Species $\times$ Water regime & 2.40446 & 0.80149 & $2.2830 \mathrm{~ns}$ \\
\hline \multirow{3}{*}{ SDB } & Species & 17.55041 & 17.55041 & $56.9239^{* *}$ \\
\hline & Water regime & 1.70795 & 0.56932 & $1.8466 \mathrm{~ns}$ \\
\hline & Species $\times$ Water regime & 1.46857 & 0.48952 & $1.5877 \mathrm{~ns}$ \\
\hline \multirow{3}{*}{ TSDB } & Species & 38.98160 & 38.98160 & $43.3878^{\star *}$ \\
\hline & Water regime & 4.02468 & 1.34156 & $1.4932 \mathrm{~ns}$ \\
\hline & Species $\times$ Water regime & 4.89128 & 1.63043 & $1.8147 \mathrm{~ns}$ \\
\hline \multirow{3}{*}{$\mathrm{RDB}$} & Species & 21.37518 & 21.37518 & $441.4331^{\star}$ \\
\hline & Water regime & 2.33289 & 0.77763 & $16.0593 \mathrm{~ns}$ \\
\hline & Species $\times$ Water regime & 1.82728 & 0.60909 & $12.5788^{* *}$ \\
\hline \multirow{3}{*}{ TDB } & Species & 2.62503 & 2.62503 & $2.3976 \mathrm{~ns}$ \\
\hline & Water regime & 5.93293 & 1.97764 & $1.8063 \mathrm{~ns}$ \\
\hline & Species $\times$ Water regime & 10.32276 & 3.44092 & $3.1429 \mathrm{~ns}$ \\
\hline \multirow{3}{*}{ RDB/TSDB } & Species & 12.04512 & 12.04512 & $94.1008^{* *}$ \\
\hline & Water regime & 0.33523 & 0.11174 & $0.8730 \mathrm{~ns}$ \\
\hline & Species $\times$ Water regime & 0.19466 & 0.06489 & $0.5069 \mathrm{~ns}$ \\
\hline \multirow{3}{*}{ LA } & Species & 4064 & 4063,8 & $0.4229 \mathrm{~ns}$ \\
\hline & Water regime & 7478 & 2492,7 & $0.2623 \mathrm{~ns}$ \\
\hline & Species $\times$ Water regime & 33466 & 11155,5 & $1.1730 \mathrm{~ns}$ \\
\hline
\end{tabular}

F: $\mathrm{F}$ test. ${ }^{* *}$ significant at $1 \%$ probability level $(\mathrm{p} \leq 0.01)$. ${ }^{*}$ significant at $5 \%$ probability level $(0.01 \leq \mathrm{p} \leq 0.05)$; ns: not significant $(\mathrm{p} \geq 0.05)$.
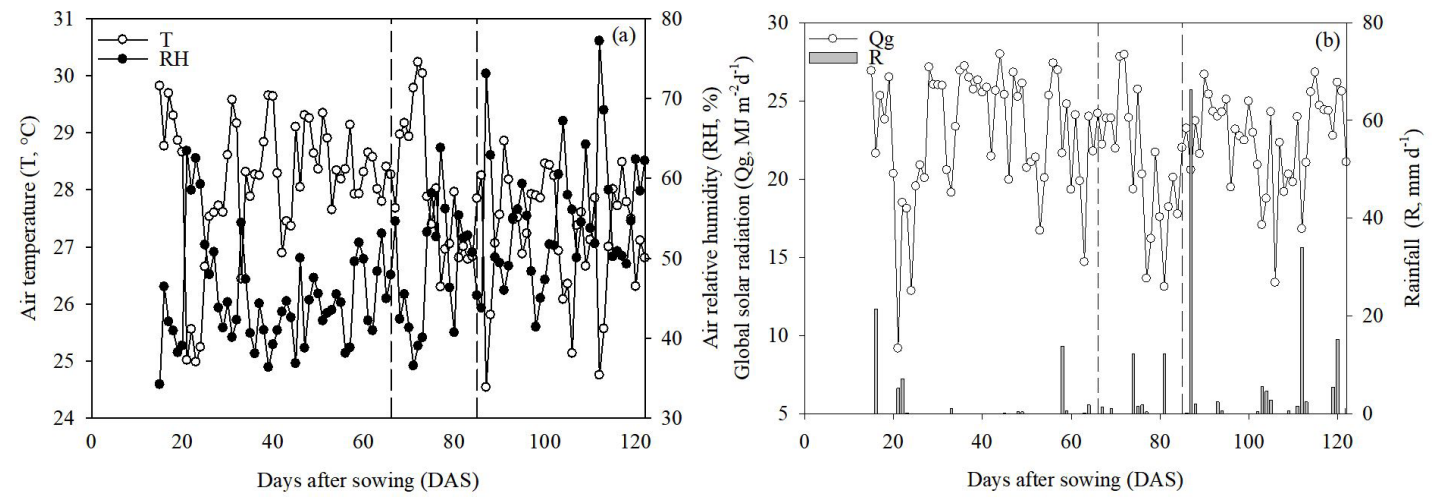

Figure 1. Weather variables (a - air temperature $(\mathrm{T})$ and air relative humidity $(\mathrm{RH})$; b - global solar radiation (Qg) and rainfall (R)) monitored of a weather station owned by the National Institute of Meteorology (INMET) over the experiment, from November 23, 2016 to March 28, 2017.

and mixed with manure and coconut fiber. At 72 days after sowing (February 6, 2017), the differentiation of the water regime started using the percentages related to the reference evapotranspiration of: $25 \% \mathrm{ET}_{0}, 50 \%$ $\mathrm{ET}_{0 ;} 75 \% \mathrm{ET}_{0}$ and $100 \% \mathrm{ET}_{0}$, lasting 15 days. The $\mathrm{ET}_{0}$ was calculated using the Penman-Monteith equation parameterized in FAO Bulletin no. 56 (Allen et al., 1998) to perform water replenishment.

\subsection{Dry biomass of the species and leaf area}

Over the cycle, at 10-day average intervals, three seedlings per treatment were obtained, and then subdivided into their organs: stem, leaves and roots, placed in paper bags and taken to the forced air ventilation oven at $60^{\circ} \mathrm{C}$ until reaching constant weight. From that information, the following were determined: leaf dry 
biomass ( $\mathrm{LDB}, \mathrm{g} \mathrm{pl}^{-1}$ ), stem dry biomass (SDB, $\mathrm{g} \mathrm{pl}^{-1}$ ), root dry biomass $\left(\mathrm{RDB}, \mathrm{g} \mathrm{pl}^{-1}\right)$, plant total dry biomass $\left(\mathrm{TDB}=\mathrm{LDB}+\mathrm{SDB}+\mathrm{RDB}, \mathrm{g} \mathrm{pl}^{-1}\right)$, total aerial part dry biomass (TAPDB $=\mathrm{LDB}+\mathrm{SDB}, \mathrm{g} \mathrm{pl}^{-1}$ ). In addition, information on partitioning was obtained: LDB/ TAPDB, SDB/TAPDB and RDB/TAPDB.

Leaf area (LF, $\left.\mathrm{cm}^{2} \mathrm{pl}^{-1}\right)$ was measured from leaf scanning using a commercial printer (model: Deskjet F4200 series, HP). The images were obtained in JPEG format and processed in the software LAfore (Veiko Lehsten) to delimit the leaf shape and, consequently, data on the leaf area.

\subsection{Model used for adjustment of the species biomass variables}

Non-linear regressions were adjusted to data of total dry matter biomass of the aerial part (TAPDB) for both species as a function of the independent variables: Days After Sowing (DAS) and Accumulated Degree-Day (ADD). The ADD was calculated using the expression (Equation 1):

$$
\mathrm{ADD}=\sum_{\mathrm{i}=1}^{\mathrm{n}}\left(\mathrm{t}_{\text {average }}-\mathrm{t}_{\mathrm{b}}\right)
$$

where, $\mathrm{t}_{\text {average }}$ is the daily average temperature $\left({ }^{\circ} \mathrm{C}\right)$ and $\mathrm{t}_{\mathrm{b}}$ is the basal temperature $\left({ }^{\circ} \mathrm{C}\right)$, considered equal to $\mathrm{tb}=10^{\circ} \mathrm{C}$ as well as for the farming crops (Batista et al., 2013).

The following models were adjusted to $P$. stipulacea using SigmaPlot ${ }^{\circledast} 10$ (Systat Software Inc.): Gaussiano (Equation 2), Lorentzian (Equation 3), Log-Normal (Equation 4) and Gompertz (Equation 5):

$$
\begin{aligned}
& y=y_{0}+a * e^{\left[-0,5 *\left(\frac{x-x_{0}}{b}\right)^{2}\right]} \\
& \mathrm{y}=\mathrm{y}_{0}+\frac{\mathrm{a}}{1+\left(\frac{\mathrm{x}-\mathrm{x}_{0}}{\mathrm{~b}}\right)^{2}} \\
& \mathrm{y}=\mathrm{y}_{0}+\mathrm{a} * \mathrm{e}^{\left[-0,5 *\left(\frac{\ln \left(\frac{\mathrm{x}}{\mathrm{x}_{0}}\right)}{\mathrm{b}}\right)^{2}\right]} \\
& y=y_{0}+a^{*} e^{-\left(\frac{x-x_{0}}{b}\right)}
\end{aligned}
$$

For A. colubrina, the 3-parameter Exponential model was used (Equation 6).

$y=y_{0}+a * e^{b * x}$

For all situations, the value of " $y$ " was the predicted variable (TAPDB) and " $x$ " was the independent variables DAS or ADD. On the other hand, "y0" " $a$ ", "b" and " $x 0$ " indicated the constants of each equation.

The parameters of the models were statistically analyzed and had the significance compared by Student's t test. In addition, the observed and estimated values were compared by application of the statistical indices. Therefore, the following were considered: Pearson's correlation coefficient (R), coefficient of determination $\left(\mathrm{r}^{2}\right)$ and the concordance index $\mathrm{d}$ (Willmott et al., 1985). In addition, the following statistical errors were estimated: mean absolute error (MAE) and root mean of the square error (SRMSE) (quoted by Oliveira et al., 2015) and the c performance coefficient of Camargo and Sentelhas (Camargo \& Sentelhas, 1997).

\subsection{Statistical analysis of the data}

The information on the biomass accumulation for the species was submitted to the Shapiro-Wilk's test and when the normality of the residues was verified, the Analysis of Variance (ANOVA) was applied, considering the $2 \times 4$ factorial arrangement (Species $\times$ Water regimes) and comparison of the means was performed by the Tukey's test at the 5\% level of significance, using ASSISTAT v7.7 software (Silva \& Azevedo, 2016).

\section{RESULTS AND DISCUSSION}

\subsection{Biomass and its partitioning}

All variables studied were affected by the species $(p<0.05)$, with exception of the LA (Table 1$)$. There was an isolated effect of the water regime only for the RDB. There was interaction effect of the water regime and species only for the RDB. This result indicates that the occurrence of short periods of water deficit (represented by the differentiation of the water regime resupply) did not promote significant changes in the growth of the aerial part dry matter of these species. Silva et al. (2015) found different results when analyzed the influence of the water regime on the species Prosopis juliflora Sw (DC.) and Caesalpinia pyramidalis Tul., 
which reduced their dry biomass due to the decrease in the water availability.

P. stipulacea was the species that most accumulated LDB and SDB over time (Figures $2 a$ and $2 b$ ), and consequently in TAPDB (Figure 2c), while A. colubrina had prominence for the parameter RDB (Figure 2d). As a consequence, there was no difference in TDB between species (Figure 2e). This is because P. stipulacea
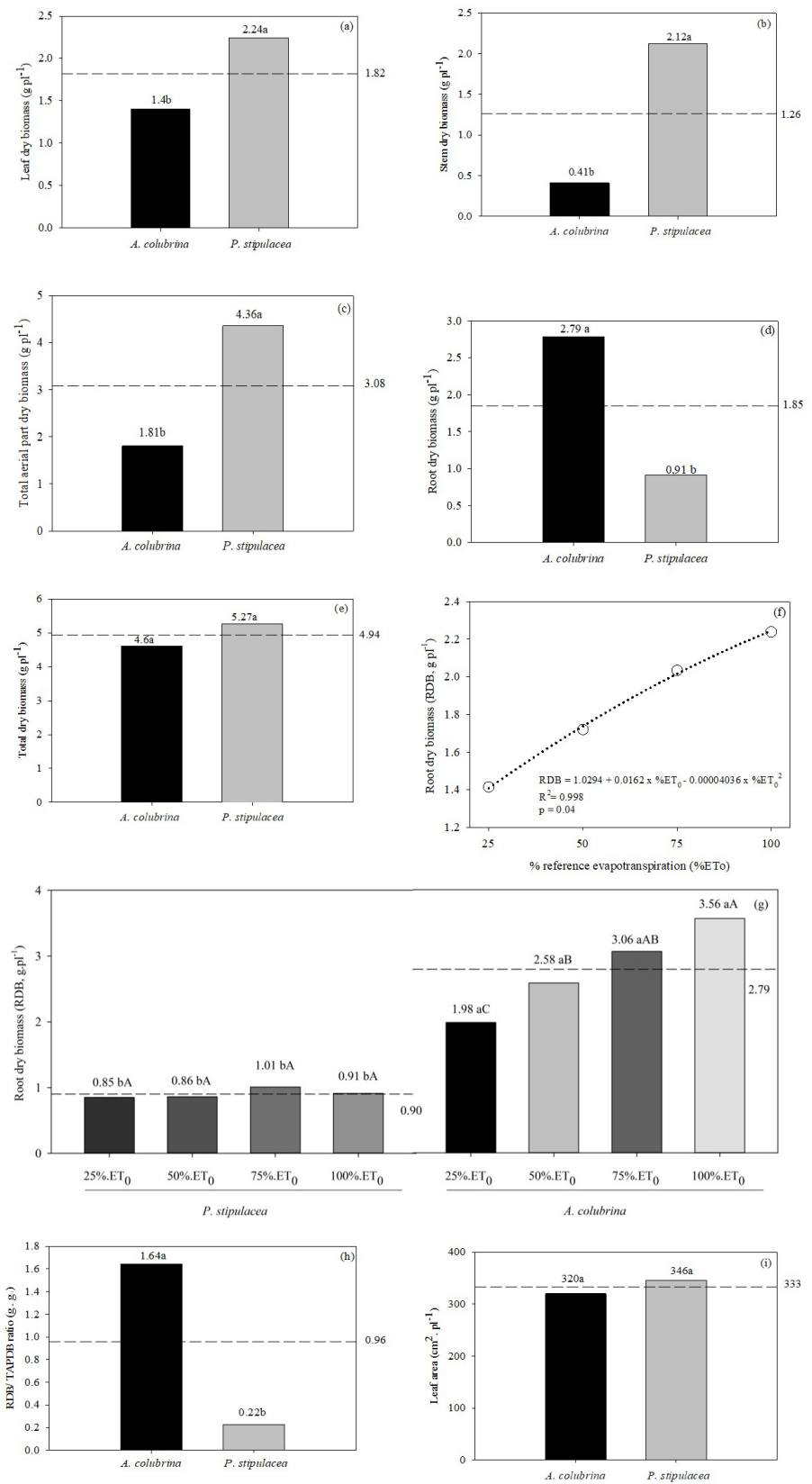

Figure 2. Comparison of biomass and leaf area parameters for A. colubrina and P. stipulacea on different water regime in the municipality of Serra Talhada, state of Pernambuco. Means followed by same lower case letters between species do not differ significantly by Tukey's test, at $5 \%$ probability. Means followed by same capital letters between water regimes do not differ significantly by Tukey's test, at $5 \%$ probability. The graphs a, b, c, d, e, h and i indicate the effect of the species on leaf dry biomass, stem dry biomass, total area part dry biomass - TAPDB, root dry biomass - RDB, total dry biomass, RDB/TAPDB ratio and leaf area, respectably. The graph $\mathrm{f}$ indicates effect of the water regime on RDB. The graph $g$ indicates the effect of the interaction between species and water regime on RDB. 
invests more in the structure of the aerial part in its growth process, showing high values of LDB and SDB when compared to A. colubrina. These growths are characteristics intrinsic of each of the species.

The investment in LDB helps $P$. stipulacea to maximize the use of radiation, while $A$. colubrina tends to invest more in support structures with greater allocation of RDB and formation of tubers to promote energy reserves in the form of starch for longer, similar to the results reported by Ferreira et al. (2012). Initially, the greater allocation of photoassimilates for the formation of leaf biomass is important to enable the realization of the photosynthetic process and, as consequence, the plant growth (Gonçalves et al., 2012). On the other hand, the reduction in the values of this partitioning over time occurred in detriment to the greater growth of the support structures, in this case, the stem with a wide presence of aculeus to avoid the herbivorous animals (Souza et al., 2013).

The increment of the water regime increased the biomass destined to the root system (Figure $2 \mathrm{f}$ ). The evolution of root dry biomass of $P$. stipulacea is more sensitive to low water availability compared to A. colubrina (Figure 2g). For the species $P$. stipulacea there was no reduction of root growth due to the application of the water regime treatments of $25 \%$. $\mathrm{ET}_{0}$ to $100 \% . \mathrm{ET}_{0}$. The capacity of biomass increase by $P$. stipulacea under reduced water conditions can be related to the plant architecture, molded to the establishment in those conditions, and can serve as a material for reforestation and conservation of dry tropical forests (Lenhard et al., 2010). For the species A. colubrina, there is an upward accumulation of root biomass for all treatments, with higher rates in the regime of $100 \% \cdot \mathrm{ET}_{0}$.

The species $P$. stipulacea showed lower LDB/TDB ratios (Figure 2h), whereas it did not present differences in leaf area in relation to A. colubrina (Figure $2 \mathrm{i}$ ). According to Ferreira et al. (2012), the investment in the A. colubrina root biomass is related to soil water availability as a resilience mechanism to remain in the environment during the period of water shortage. This strategy makes it possible the contact of the plant with deeper layers of soil that subsidize access to water. Additionally, Matos et al. (2018), when studying the initial growth of Tectona grandis also verified strategies of resistance to water deficit, such as greater stomatal resistance and reduction of leaf surface, ensuring the establishment of the plant in the environment. The most pronounced development of the A. colubrina root system is the establishment of seedling during reforestation actions, since the occurrence of prolonged summer can lead to a decline in the growth of the species in the field. Figueirôa et al. (2004), evaluating morphogenesis of Myracroduon urundeuva Allemão (Anacardiaceae), showed high values of dry biomass of the plant under low water conditions.

\subsection{Biomass modeling of Caatinga species}

For P. stipulacea, the adjustment of the Gaussian, Lorentzian and Log-Normal models were significant by the $t$ test at the $5 \%$ level (Table 2) for all treatments. The Gompertz model not adjusted only for treatment of $25 \% . \mathrm{ET}_{0}$. The validation of these three models is presented in the Table 3. For A. colubrina, the only model that presented good adjustments was the Exponential. The model constants and your validation were presented in the Table 4 . This behavior is probably associated with the fact that the initial growth of A. colubrina occurs in a mild manner (Ferreira et al., 2012), which is the reason for its permanence in the initial stage of growth.

The Gaussian, Lorentzian and Log-Normal models express the evolution of the accumulated biomass of the species until reaching the maximum magnitude (parameter "a"), which occurs at a specific plant development time (parameter " $\mathrm{x} 0$ ” (days or $\left.{ }^{\circ} \mathrm{C}\right)$ ). The number of days required to start the maximum biomass is explained by parameter " $b$ " (days or ${ }^{\circ} \mathrm{C}$ ). Before this time ("b") occurs the first phase of growth of the plant characterized by slow growth, which starts at time " $x=0$ " when the initial biomass is equal to " $y 0$ ". From time " $\mathrm{x} 0$ ", the biomass of the species tends to reduce until the end of the experimental period. This behavior is not observed in the Gompertz model, since the maximum biomass remains constant until the end of the experimental period. In turn, for the exponential model does not present the point of stabilization of the maximum accumulation of biomass.

The highest values of the "a" parameter of the Gaussian, Lorentzian and Log-Normal models occur between the water regimes of $75 \% . \mathrm{ET}_{0}$ and $100 \%$. $\mathrm{ET}_{0}$ depending on the model (Table 2). The other parameters ("y0", "x0" and "b") did not present a 
Table 2. Constant (CM) of the Gaussian (G), Lorentzian (L), Log-Normal (LN) and Gompertz (GO) Models for the adjustment of Total Aerial Part Dry Biomass (TAPDB) of P. stipulacea in the municipality of Serra Talhada, state of Pernambuco from November 23, 2016 to March 28, 2017, using as the Independent Variable (VI), Days After Sowing (DAS) and Accumulated Degree-Days (ADD) for the following relative percentages (T): $25 \% . \mathrm{ET}_{0}$ (T1), 50\%. $\mathrm{ET}_{0}(\mathrm{~T} 2), 75 \% \cdot \mathrm{ET}_{0}(\mathrm{~T} 3)$ and $100 \% . \mathrm{ET}_{0}(\mathrm{~T} 4)(\mathrm{p}<0.05)$.

\begin{tabular}{|c|c|c|c|c|c|c|c|c|c|}
\hline \multirow{3}{*}{$\mathbf{T}$} & \multirow{3}{*}{$\mathbf{C M}$} & \multicolumn{2}{|c|}{ G MODEL } & \multicolumn{2}{|c|}{ L MODEL } & \multicolumn{2}{|c|}{ LN MODEL } & \multicolumn{2}{|c|}{ GO MODEL } \\
\hline & & \multicolumn{2}{|c|}{ VI } & \multicolumn{2}{|c|}{ VI } & \multicolumn{2}{|c|}{ VI } & \multicolumn{2}{|c|}{ VI } \\
\hline & & DAS & ADD & DAS & ADD & DAS & ADD & DAS & ADD \\
\hline \multirow{4}{*}{ T1 } & y0 & 0.19 & 0.13 & -0.79 & -0.79 & - & - & - & - \\
\hline & $\mathbf{x} 0$ & 90.93 & 1332.8 & 91.04 & 1335.9 & 88.48 & 1277.9 & - & - \\
\hline & $\mathbf{a}$ & 2.71 & 2.75 & 3.75 & 3.74 & 2.89 & 2.80 & - & - \\
\hline & b & 17.96 & 324.48 & 27.02 & 476.36 & 0.21 & 0.26 & - & - \\
\hline \multirow{4}{*}{ T2 } & y0 & 0.92 & 1.03 & -0.29 & -0.11 & 1.3 & 1.39 & - & - \\
\hline & $\mathbf{x} 0$ & 126.02 & 1937.9 & 123.81 & 1900.3 & 132.33 & 2068.7 & 70.29 & 988.27 \\
\hline & $\mathbf{a}$ & 3.14 & 3.04 & 4.36 & 4.19 & 2.81 & 2.72 & 5.17 & 5.32 \\
\hline & b & 35.83 & 600.77 & 53.13 & 885.69 & 0.35 & 0.39 & 36.8 & 681.24 \\
\hline \multirow{4}{*}{ T3 } & y0 & 0.86 & 0.95 & -0.49 & -0.36 & - & - & - & - \\
\hline & x0 & 20.99 & 1852.2 & 119.56 & 1828.8 & 141.92 & 2446.6 & 71.89 & 1007.6 \\
\hline & $\mathbf{a}$ & 3.76 & 3.67 & 5.16 & 5.02 & 4.80 & 4.99 & 5.46 & 5.56 \\
\hline & b & 30.82 & 520.8 & 45.14 & 762.31 & 0.51 & 0.66 & 28.13 & 513.83 \\
\hline \multirow{4}{*}{ T4 } & yo & - & - & - & - & - & - & - & - \\
\hline & $\mathbf{x} 0$ & 116.15 & 1775.6 & 114.93 & 1750.5 & 119.57 & 1881.3 & 66.98 & 910.85 \\
\hline & $\mathbf{a}$ & 4.01 & 4.00 & 4.10 & 4.08 & 3.94 & 3.94 & 4.19 & 4.23 \\
\hline & b & 35.94 & 632.33 & 40.5 & 708.1 & 0.42 & 0.52 & 18.44 & 338.5 \\
\hline
\end{tabular}

Table 3. Validation Parameters (VP) for Gaussian (G), Lorentzian (L), Log-Normal (LN) and Gompertz (GO) models for adjustment of Total Aerial Part Dry Biomass (TAPDB) of $P$. stipulacea in the municipality of Serra Talhada, state of Pernambuco from November 23, 2016 to March 28, 2017, using as the Independent Variable (VI), the Days After Sowing (DAS) and Accumulated Degree-Days (ADD) for the following relative percentages (T): $25 \%$. $\mathrm{ET}_{0}(\mathrm{~T} 1), 50 \% \cdot \mathrm{ET}_{0}(\mathrm{~T} 2), 75 \% \cdot \mathrm{ET}_{0}(\mathrm{~T} 3)$ and $100 \% \cdot \mathrm{ET}_{0}(\mathrm{~T} 4)(\mathrm{p}<0.05)$.

\begin{tabular}{|c|c|c|c|c|c|c|c|c|c|}
\hline \multirow{3}{*}{$\mathbf{T}$} & \multirow{3}{*}{ VP } & \multirow{2}{*}{\multicolumn{2}{|c|}{$\frac{\text { G MODEL }}{\text { VI }}$}} & \multirow{2}{*}{\multicolumn{2}{|c|}{ L MODEL }} & \multirow{2}{*}{\multicolumn{2}{|c|}{ LN MODEL }} & \multirow{2}{*}{\multicolumn{2}{|c|}{$\frac{\text { GO MODEL }}{\mathrm{VI}}$}} \\
\hline & & & & & & & & & \\
\hline & & DAS & ADD & DAS & ADD & DAS & ADD & DAS & ADD \\
\hline \multirow{6}{*}{ T1 } & $\mathbf{R}$ & 0.9876 & 0.9833 & 0.99 & 0.9858 & 0.9556 & 0.9354 & - & - \\
\hline & $\mathbf{r}^{2}$ & 0.9753 & 0.9668 & 0.9801 & 0.9717 & 0.9132 & 0.8749 & - & - \\
\hline & d & 0.9949 & 0.9931 & 0.9949 & 0.9927 & 0.9767 & 0.9654 & - & - \\
\hline & c & 0.9825 & 0.9765 & 0.9849 & 0.9786 & 0.9333 & 0.903 & - & - \\
\hline & MAE & $-6.18 \times 10^{-6}$ & $-2.85 \times 10^{-6}$ & $3.3 \times 10^{-5}$ & $6.0 \times 10^{-5}$ & 0.0009 & 0.0006 & - & - \\
\hline & SRMSE & 0.14 & 0.16 & 0.13 & 0.15 & 0.27 & 0.32 & - & - \\
\hline \multirow{6}{*}{ T2 } & $\mathbf{R}$ & 0.9988 & 0.9992 & 0.9991 & 0.9995 & 0.9983 & 0.9987 & 0.9961 & 0.996 \\
\hline & $\mathbf{r}^{2}$ & 0.9977 & 0.9985 & 0.9983 & 0.999 & 0.9967 & 0.9974 & 0.9921 & 0.9919 \\
\hline & d & 0.9995 & 0.9997 & 0.9995 & 0.9997 & 0.9991 & 0.9993 & 0.998 & 0.9979 \\
\hline & c & 0.9983 & 0.9989 & 0.9986 & 0.9992 & 0.9974 & 0.998 & 0.9941 & 0.9939 \\
\hline & MAE & $6.13 \times 10^{-5}$ & $5.13 \times 10^{-5}$ & $2.96 \times 10^{-5}$ & $-6.7 \times 10^{-5}$ & -0.0002 & 0.0002 & -0.0005 & -0.0006 \\
\hline & SRMSE & 0.04 & 0.04 & 0.04 & 0.03 & 0.05 & 0.05 & 0.08 & 0.08 \\
\hline \multirow{6}{*}{ T3 } & $\mathbf{R}$ & 0.9835 & 0.9846 & 0.9843 & 0.9854 & 0.9793 & 0.9787 & 0.9781 & 0.9785 \\
\hline & $\mathbf{r}^{2}$ & 0.9673 & 0.9695 & 0.9688 & 0.9709 & 0.959 & 0.9579 & 0.9567 & 0.9785 \\
\hline & d & 0.9922 & 0.9928 & 0.992 & 0.9925 & 0.9894 & 0.9892 & 0.9888 & 0.9575 \\
\hline & c & 0.9759 & 0.9775 & 0.9764 & 0.978 & 0.969 & 0.9681 & 0.9672 & 0.989 \\
\hline & MAE & $-3.37 \times 10^{-5}$ & $8.23 \times 10^{-5}$ & $-6.8 \times 10^{-5}$ & $-2.8 \times 10^{-5}$ & -0.003 & -0.0033 & -0.0015 & -0.0017 \\
\hline & SRMSE & 0.22 & 0.21 & 0.21 & 0.2 & 0.24 & 0.24 & 0.25 & 0.25 \\
\hline \multirow{6}{*}{ T4 } & $\mathbf{R}$ & 0.9816 & 0.9802 & 0.9694 & 0.9693 & 0.983 & 0.983 & 0.9795 & 0.9766 \\
\hline & $\mathbf{r}^{2}$ & 0.9635 & 0.9608 & 0.9397 & 0.9395 & 0.9664 & 0.9664 & 0.9595 & 0.9538 \\
\hline & d & 0.9923 & 0.9928 & 0.9835 & 0.9835 & 0.9914 & 0.9897 & 0.9896 & 0.9881 \\
\hline & c & 0.974 & 0.9731 & 0.9534 & 0.9533 & 0.9745 & 0.9729 & 0.9693 & 0.965 \\
\hline & MAE & 0.0017 & 0.001 & 0.0133 & 0.0126 & -0.0023 & -0.0037 & -0.0029 & -0.003 \\
\hline & SRMSE & 0.20 & 0.20 & 0.25 & 0.25 & 0.19 & 0.20 & 0.21 & 0.22 \\
\hline
\end{tabular}


Table 4. Model Constants (MC) and Validation Parameters (VP) of the Exponential Model for adjustment of the Total Aerial Part Dry Biomass (TAPDB) of A. colubrina in the municipality of Serra Talhada, state of Pernambuco from November 23, 2016 to March 28, 2017, using as the Independent Variable (VI), the Days After Sowing (DAS) and Accumulated Degree-Days (ADD) for the following relative percentages (T): 25\%.ET $\left(\mathrm{T} 1\right.$ ), $50 \% . \mathrm{ET}_{0}$ (T2), $75 \%$. $\mathrm{ET}_{0}(\mathrm{~T} 3)$ and $100 \% . \mathrm{ET}_{0}(\mathrm{~T} 4)(\mathrm{p}<0.05)$.

\begin{tabular}{|c|c|c|c|c|c|c|c|}
\hline \multirow{3}{*}{$\mathbf{T}$} & \multirow{3}{*}{ MC } & \multicolumn{2}{|c|}{ TAPDB } & \multirow{3}{*}{$\mathbf{T}$} & \multirow{3}{*}{ VP } & \multirow{2}{*}{\multicolumn{2}{|c|}{$\begin{array}{c}\text { TAPDB } \\
\text { VI } \\
\end{array}$}} \\
\hline & & & & & & & \\
\hline & & DAS & ADD & & & DAS & ADD \\
\hline \multirow{6}{*}{$\mathrm{T} 1$} & \multirow{2}{*}{ y0 } & \multirow{2}{*}{0.5597} & \multirow{2}{*}{0.5658} & \multirow{6}{*}{$\mathrm{T} 1$} & $\mathrm{R}$ & 0.9791 & 0.9783 \\
\hline & & & & & $r^{2}$ & 0.9587 & 0.9571 \\
\hline & a & 00005 & 00009 & & d & 0.9999 & 1 \\
\hline & a & 0.0000 & 0.000 & & c & 0.979 & 0.9783 \\
\hline & \multirow{2}{*}{ b } & \multirow{2}{*}{0.0615} & \multirow{2}{*}{0.0037} & & MAE & 0.021 & 0.0251 \\
\hline & & & & & SRMSE & 0.08 & 0.09 \\
\hline \multirow{6}{*}{$\mathrm{T} 2$} & \multirow{2}{*}{ y0 } & \multirow{2}{*}{ - } & \multirow{2}{*}{ - } & \multirow{6}{*}{ T2 } & $\mathrm{R}$ & 0.9349 & 0.9365 \\
\hline & & & & & $r^{2}$ & 0.8741 & 0.8771 \\
\hline & \multirow{4}{*}{ b } & \multirow{2}{*}{0.1765} & \multirow{2}{*}{0.2236} & & d & 0.9999 & 0.9999 \\
\hline & & & & & $\mathrm{c}$ & 0.9348 & 0.9364 \\
\hline & & 0.0171 & 0.001 & & MAE & 0.0034 & 0.0195 \\
\hline & & & & & SRMSE & 0.13 & 0.13 \\
\hline \multirow{6}{*}{ T3 } & \multirow{2}{*}{ y0 } & \multirow{2}{*}{ - } & \multirow{2}{*}{-} & \multirow{6}{*}{ T3 } & $\mathrm{R}$ & 0.9485 & 0.9474 \\
\hline & & & & & $r^{2}$ & 0.8997 & 0.8976 \\
\hline & \multirow{4}{*}{ b } & \multirow{2}{*}{0.1635} & \multirow{2}{*}{0.2195} & & d & 1 & 0.9999 \\
\hline & & & & & c & 0.9485 & 0.9473 \\
\hline & & 00214 & 00012 & & MAE & 0.0026 & -0.073 \\
\hline & & 0.0214 & 0.0012 & & SRMSE & 0.2 & 0.22 \\
\hline & $\mathrm{v}$ & - & 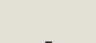 & & $\mathrm{R}$ & 0.9629 & 0.9606 \\
\hline & yo & - & - & & $r^{2}$ & 0.9272 & 0.9228 \\
\hline T4 & a & 0.2257 & 0.2877 & T4 & d & 0.9976 & 0.9975 \\
\hline 14 & a & 0.2257 & 0.2017 & 14 & c & 0.9606 & 0.9581 \\
\hline & b & 0.0171 & 0.001 & & MAE & -0.006 & 0.0214 \\
\hline & & 0.0171 & 0.001 & & SRMSE & 0.12 & 0.13 \\
\hline
\end{tabular}

trend as the water regime increased, which may be associated with the intrinsic response of the species to each water availability condition. For the exponential model, there is no trend of changing the parameters according to the variation of the water regime. These results are typical of semiempirical models (Batista et al., 2013).

The efficiency of the models was observed by the Pearson's correlation coefficient (R) and the coefficient of determination $\left(\mathrm{r}^{2}\right)$ that reached values higher than $80 \%$, as well as the Willmott concordance index (d) and the performance index proposed by Camargo and Sentelhas (c). For other species, adequate adjustments of Logistic and Gompertz models were observed (Batista et al., 2013; Fernandes et al., 2017). Moreover, a high accuracy of the Gaussian, Lorentzian, Log-Normal, Gompertz and Exponential models were classified as
"Excellent" for the TAPDB of the species analyzed on different water regime replenish, where VI DAS and ADD (c>0.85) (Tables 3 and 4).

In some cases, mild overestimations or underestimations were observed using mean absolute error (MAE) and square root mean square error (SRMSE) (Table 3 and 4). In the studies on the initial growth of Prosopis juliflora Sw (DC.), an invasive species and Caesalpinia pyramidalis Tul., a native species, Silva et al. (2015) adjusted several physical models, among them, the Gaussian and Gompertz to estimate dry biomass as a function of water availability. These researchers obtained excellent values for the validation parameters $\mathrm{R}, \mathrm{d}, \mathrm{c}, \mathrm{MAE}$ and SRMSE, where the Gompertz model excelled with optimal accuracy (d close to 1 ) using GDA values. 


\section{CONCLUSIONS}

The short period of water scarcity in the initial growth phase of $P$. stipulacea and $A$. colubrina does not affect the establishment of these species, but different water regimes alter their root growth dynamics. The A. colubrina allocates more dry matter to the roots, while $P$. stipulacea sends more dry matter to the aerial part. The Gaussian, Lorentzian, Log-Normal and Gompertz models had excellent adjustments for the biomass variables of the $P$. stipulacea species, whereas for A. colubrina, the Exponential model is recommended.

\section{ACKNOWLEDGEMENTS}

Núcleo de Ecologia e Monitoramento Ambiental (NEMA) - UNIVASF e a Embrapa Semiárido.

\section{SUBMISSION STATUS}

Received: 9 aug., 2018

Accepted: 12 aug., 2019

\section{CORRESPONDENCE TO}

\section{Thieres George Freire da Silva}

Unidade Acadêmica de Serra Talhada, Universidade Federal Rural de Pernambuco UFRPE, Avenida Gregório Ferraz Nogueira, s/n, Serra Talhada, CEP 52171-900, Recife, PE, Brasil e-mail: thieres_freire@yahoo.com.br

\section{REFERENCES}

Allen RG, Pereira LS, Raes D, Smith M. Crop evapotranspiration: guidelines for computing crop water requirements. 1st ed. Rome: FAO; 1998

Alvalá RCS, Cunha APMA, Brito SSB, Seluchi ME, Marengo JA, Moraes OLL et al. Drought monitoring in the Brazilian Semiarid region. Anais da Academia Brasileira de Ciências 2017; 91(suppl. 1): e20170209. PMid:29044320.

Batista ELS, Zolnier S, Ribeiro A, Lyra GB, Silva TGF, Boehringer D. Modelagem do crescimento de cultivares de cana-de-açúcar no período de formação da cultura. Revista Brasileira de Engenharia Agrícola e Ambiental 2013; 17(10): 1080-1087. http://dx.doi.org/10.1590/ S1415-43662013001000009.

Camargo AP, Sentelhas PC. Avaliação do desempenho de diferentes métodos de estimativa da evapotranspiração potencial no Estado de São Paulo, Brasil. Revista Brasileira de Agrometeorologia 1997; 5(1): 89-97.

Costa AS, Freire ALO, Bakke IA, Pereira FHF. Respostas fisiológicas e bioquímicas de plantas de aroeira (Myracrondruon urundeuva Allemão) ao déficit hídrico e posterior recuperação. Irriga 2015; 20(4): 705-717. http:// dx.doi.org/10.15809/irriga.2015v20n4p705.

Fernandes TJ, Pereira AA, Muniz JA. Double sigmoidal describing the growth of coffee berries. Ciência Rural 2017; 47(8): 1-7. http://dx.doi.org/10.1590/0103-8478cr20160646.

Ferreira WN, Zandavalli RB, Bezerra AME, MedeirosFilho S. Crescimento inicial de Piptadenia stipulacea (Benth.) Ducke (Mimosaceae) e Anadenanthera colubrina (Vell.) Brenan var. cebil (Griseb.) Altshul (Mimosaceae) sob diferentes níveis de sombreamento. Acta Botanica Brasílica 2012; 26(2): 408-414. http://dx.doi.org/10.1590/ S0102-33062012000200016.

Figueiredo-Lima KV, Falcão HM, Melo-de-Pinna GF, Albacete A, Dodd IC, Lima AL et al. Leaf phytohormone levels and stomatal control in an evergreen woody species under semiarid environment in a Brazilian seasonally dry tropical forest. Plant Growth Regulation 2018; 85(3): 437-445. http://dx.doi.org/10.1007/s10725-018-0405-5.

Figueirôa JM, Barbosa DCA, Simabukuro EA. Crescimento de plantas jovens de Myracroduon urundeuva Allemão (Anacardiaceae) sob diferentes regimes hídricos. Acta Botanica Brasílica 2004; 18(3): 573-580. http://dx.doi. org/10.1590/S0102-33062004000300015.

Gonçalves EO, Paiva HN, Neves JCL, Gomes JM. Nutrição de mudas de angico-vermelho (Anadenantheramacrocarpa (Benth.)Brenan) submetidas a doses de N, P, K, Ca e Mg. Revista Árvore 2012; 36(2): 219-228. http://dx.doi. org/10.1590/S0100-67622012000200003.

Gonçalves JFC, Melo EGF, Ferreira MJ, Silva CEM, Gomes IA. Crescimento, partição de biomassa e fotossíntese em plantas jovens de Genipas pruceana submetidas ao alagamento. Cerne 2013; 19(2): 193-200. http://dx.doi. org/10.1590/S0104-77602013000200003.

Lenhard RN, Scalon SPQ, Novelino JO. Crescimento inicial de mudas de pau-ferro (Caesalpinea férrea MART. Ex Tul. Var. leiostachya Benth.) sob diferentes regimes hídricos. Ciência e Agrotecnologia 2010; 34(4): 870-877. http://dx.doi.org/10.1590/S1413-70542010000400011.

Lorenzi H. Árvores Brasileiras: manual de identificação e cultivo de plantas arbóreas nativas do Brasil. 1 ed. Odessa: Plantarum; 2009.

Lúcio DM, Dantas SG, Santos JRM, Praxedes SC. Differences in water deficit adaptation during early growth of Brazilian dry forest Caatinga trees. Agriculture \& Forestry 2017; 63(2): 59-68. http://dx.doi.org/10.17707/ AgricultForest.63.2.05.

Matos FS, Freitas IAS, Souza BR, Lopes VA, Rosa VR. Crescimento de plantas de Tectona grandis sob restrição 
hídrica. Revista Agrian 2018; 11(39): 14-21. http://dx.doi. org/10.30612/agrarian.v11i39.5284.

Menezes RSC, Sampaio EVSB, Giongo V, Perez-Marin AM. Biogeochemical cycling in terrestrial ecosystems of the Caatinga Biome. Brazilian Journal of Biology = Revista Brasileira de Biologia 2012;72(3, suppl.): 643-653. http://dx.doi.org/10.1590/S1519-69842012000400004. PMid:23011295.

Oliveira RLL, Moreira AR, Costa AVA, Souza LC, Lima LGS, Silva RTL. Modelos de determinação não destrutiva de área foliar de feijão caupi Vigna unguiculata (L.). Global Science and Technology 2015; 8(2): 17-27. http://dx.doi. org/10.14688/1984-3801/gst.v8n2p17-27.

Pereira PC, Silva TGF, Zolnier S, Morais JEF, Santos DC. Morfogênese da Palma forrageira irrigada por gotejamento. Revista Caatinga 2015; 28(3): 184-195. http://dx.doi. org/10.1590/1983-21252015v28n321rc.

Pinheiro KM, Silva TGF, Diniz WJS, Carvalho HFS, Moura MSB. Indirect methods for determining the area index of forage cactus cladodes. Pesquisa Agropecuária Tropical 2015; 45(2): 163-171. http://dx.doi.org/10.1590/1983$40632015 \mathrm{v} 4530617$.

Santos HG, Almeida JA, Oliveira JB, Lumbreras JF, Anjos LHC, Coelho MR et al. Sistema brasileiro de classificação de solos. 3st ed. Brasilia: Embrapa Solos; 2013.

Silva FAS, Azevedo CAV. The Assistat Software Version 7.7 and its use in the analysis of experimental data. African
Journal of Agricultural Research 2016; 11(39): 3733-3740. http://dx.doi.org/10.5897/AJAR2016.11522.

Silva JWL, Silva TGF, Barbosa ML. Espécies Caesalpinia pyramidalis Tul. e Prosopis juliflora Sw (DC.) sob diferentes regimes hídricos: crescimento e ajuste de modelos matemáticos. Revista Brasileira de Geografia Física 2015; 8(6): 1692-1710. http://dx.doi.org/10.5935/19842295.20150096.

Silva PF, Lima JRS, Antonino CDA, Souza R, Souza ES, Silva JRI et al. Seasonal patterns of carbon dioxide, water and energy fluxes over the Caatinga and grassland in the semi-arid region of Brazil. Journal of Arid Environments 2017; 147: 71-82. http://dx.doi.org/10.1016/j.jaridenv.2017.09.003.

Soares DB, Nóbrega, RS. Análise espacial e climatológica da ocorrência de veranicos no Sertão de Pernambuco. Revija za Geografijo 2010; 27(1): 95-106.

Souza BD, Meiado MV, Rodrigues BM, Santos MG. Water relations and chlorophyll fluorescence responses of two leguminous trees from the Caatinga to different watering regimes. Acta Physiologiae Plantarum 2010; 32(2): 235-244. http://dx.doi.org/10.1007/s11738-009-0394-0.

Souza VC, Flores TB, Lorenzi H. Introdução à botânica: morfologia. São Paulo: Instituto Plantarum de Estudos da Flora; 2013

Willmott CJ, Ackleson SG, Davis RE, Feddema JJ, Klink KM, Legates DR et al. Statistics for evaluation and comparison of models. Journal of Geophysical Research 1985; 90(5): 8995-9005. http://dx.doi.org/10.1029/JC090iC05p08995. 